\title{
GAMBARAN STATUS GINGIVA MENURUT KEBIASAAN MENYIKAT GIGI SEBELUM TIDUR MALAM HARI PADA SISWA SEKOLAH DASAR NEGERI 70 MANADO
}

\author{
${ }^{1}$ Anna M. Maruanaya, \\ ${ }^{2}$ Ni Wayan Mariati, \\ ${ }^{3}$ Damajanty H. C. Pangemanan \\ ${ }^{1}$ Kandidat Skripsi Program Studi Kedokteran Gigi Fakultas Kedokteran \\ ${ }^{2}$ Program Studi Kedokteran Gigi Fakultas Kedokteran \\ ${ }^{3}$ Bagian Fisiologi Fakultas Kedokteran \\ Universitas Sam Ratulangi Manado \\ Email: ellenmaruanaya@yahoo.co.id
}

\begin{abstract}
Gingiva is a part of the oral mucosa which is closely related to the elements of teeth, interdental space, and alveolar bones. Gingival tissue health status is affected by dental and oral hygiene. Tooth brushing is needed to maintain the oral hygiene. This study aimed to obtain the gingival status related to tooth brushing before going to bed at night among students at Elementary School 70 Manado. This was a descriptive study. Samples were obtained by using total sampling technique. There were 45 students as samples. The results showed that based on gingival index, most of the students had gingival status of mild inflammation (55.6\%). Based on gingival status related to tooth brushing before going to bed, the majority of students (55.6\%) did that before going to bed at night.
\end{abstract}

Keywords: gingival status, brushing teeth before bed at night

\begin{abstract}
Abstrak: Gingiva merupakan bagian dari mukosa mulut yang memiliki hubungan erat dengan elemen-elemen gigi, ruang interdental, dan tulang alveolar. Kesehatan jaringan gingiva dipengaruhi oleh kebersihan gigi dan mulut. Salah satu cara menjaga kebersihan gigi dan mulut yaitu dengan menyikat gigi. Penelitian ini bertujuan untuk mendapatkan gambaran status gingiva menurut kebiasaan menyikat gigi sebelum tidur malam hari pada siswa di Sekolah Dasar Negeri 70 Manado. Penelitian ini merupakan menggunakan metode deskriptif dengan teknik pengambilan sampe total sampling. Jumlah sampel penelitian 45 anak. Hasil penelitian menunjukkan bahwa berdasarkan pengukuran indeks gingiva sebagian besar siswasiswi memiliki status gingiva dengan kriteria inflamasi ringan (55,6\%). Untuk status gingiva berdasarkan menyikat gigi sebelum tidur malam hari diperoleh hasil bahwa sebagian besar siswa-siswi (55,6\%) menyikat gigi sebelum tidur malam hari.
\end{abstract}

Kata kunci: status gingiva, menyikat gigi sebelum tidur malam hari

Gingiva merupakan bagian dari mukosa yang memiliki hubungan erat dengan elemen-elemen gigi, ruang interdental dan tulang alveolar. Secara topografi, gingiva dibagi dalam tiga kategori klasik yaitu gingiva bebas, gingiva cekat dan gingiva interdental. Gingiva yang sehat berwarna merah muda, tepinya seperti pisau, menutupi susunan gigi-geligi dengan mengikuti konturnya. ${ }^{1,}$

Kebersihan gigi dan mulut dapat memengaruhi kesehatan jaringan gingiva. Semakin buruk tingkat kebersihan gigi dan mulut seseorang, semakin mudah terserang gingivitis atau peradangan pada jaringan gingiva. Hal ini sejalan dengan hasil 
penelitian Hadnyanawati $^{3}$ pada siswa sekolah dasar di Jember, yang menyatakan bahwa $100 \%$ siswa dengan kebersihan gigi dan mulut yang buruk terkena gingivitis. Status kesehatan jaringan gingiva dapat diukur menggunakan indeks gingiva yang diperkenalkan oleh Loe dan Silness. ${ }^{2,3}$

Menyikat gigi merupakan pemeliharaan kebersihan gigi dan mulut yang paling umum dilakukan oleh masyarakat Indonesia. Setiap orang memiliki kebiasaan tertentu dalam melakukan penyikatan gigi. ${ }^{4}$ Menyikat gigi sebelum tidur berperan penting dalam pencegahan perkembangan bakteri yang dapat menyebabkan kerusakan gigi. Berdasarkan Riset Kesehatan Dasar (Riskesdas) 2013 tentang penyakit gigi dan mulut menunjukkan sebagian besar penduduk Indonesia yang menyikat gigi pada saat mandi pagi maupun mandi sore yaitu (76,6\%), sedangkan menyikat gigi dengan benar yaitu setelah makan pagi dan sebelum tidur malam ditemukan hanya 2,3\%. Prevalensi menyikat gigi malam sebelum tidur pada anak - anak di Indonesia sebesar 22,4\%, dan di Sulawesi Utara sebesar 32,4\%. ${ }^{5}$ Hal ini membuktikan bahwa masih banyak masyarakat yang belum menyadari akan pentingnya menyikat gigi malam sebelum tidur. ${ }^{5}$

Sekolah Dasar Negeri 70 Manado merupakan salah satu Sekolah Dasar yang ada di kecamatan Kleak Kota Manado Provinsi Sulawesi Utara. Berdasarkan survei awal yang dilakukan di SD Negeri 70 Manado, diperoleh data jumlah anak pada kelas 4, 5, dan 6 usia 10-12 tahun dengan kebiasaan menyikat gigi sebelum tidur malam hari yang berbeda-beda. Keadaan sosial ekonomi orang tua di sekolah ini tergolong menengah ke atas. Peran orang tua sangat berpengaruh terhadap pemeliharaan kebersihan gigi dan mulut anak. Tingkat pengetahuan orang tua yang berbeda juga memengaruhi pengetahuan orang tua akan pengetahuan kebersihan gigi dan mulut pada anaknya.

\section{METODE PENELITIAN}

Penelitian ini merupakan suatu penelitian deskriptif. Penelitian dilakukan di SD Negeri 70 Manado Sulawesi Utara. Waktu penelitian dilaksanakan pada bulan Juni - Juli 2015. Populasi pada penelitian ini ialah siswa-siswi Sekolah Dasar Negeri 70 Manado usia 10-12 tahun yang berjumlah 45 orang. Teknik pengambilan sampel yaitu total sampling.

\section{HASIL PENELITIAN}

Tabel 1 memperlihatkan berdasarkan jenis kelamin subjek penelitian terdiri dari 24 siswa (53,3\%) laki-laki dan 21 siswi (46,7\%) perempuan.

Tabel 1. Distribusi subjek penelitian berdasarkan jenis kelamin

\begin{tabular}{ccc}
\hline Jenis kelamin & $\mathrm{n}$ & $\%$ \\
\hline Laki-laki & 24 & 53,3 \\
Perempuan & 21 & 46,7 \\
Total & 45 & 100 \\
\hline
\end{tabular}

Berdasarkan usia subjek penelitian siswa-siswi yang berusia 10-12 tahun berjumlah 45 siswa/i yang terdiri atas: 12 anak (26,7\%) yang berusia 10 tahun; 18 anak (40\%) yang berusia 11 tahun; dan 15 anak $(33,3 \%)$ yang berusia 12 tahun.

\section{Hasil Penelitian Menyikat Gigi Malam Hari Sebelum Tidur}

Untuk mengetahui kebiasaan menyikat gigi malam sebelum tidur dilakukan dengan menggunakan kuesioner pada 45 siswasiswi yang menjadi subjek penelitian.

Pada Tabel 2 berdasarkan cara menjaga kesehatan gigi dan mulut dapat dilihat bahwa semua siswa (100\%) menyikat gigi.

Tabel 2. Distribusi subjek penelitian berdasarkan cara menjaga kesehatan gigi dan mulut

\begin{tabular}{ccc}
\hline $\begin{array}{c}\text { Cara untuk menjaga kesehatan } \\
\text { gigi dan mulut }\end{array}$ & $\mathrm{n}$ & $\%$ \\
\hline Menyikat gigi & 45 & 100 \\
Menghindari makanan/ & 0 & 0 \\
minuman manis diluar jam & & \\
makan & & \\
Tidak ada tindakan & 0 & 0 \\
Total & 45 & 100 \\
\hline
\end{tabular}


Pada Tabel 3 berdasarkan cara menyikat gigi yang benar dan baik dapat dilihat bahwa semua siswa (100\%) menyikat gigi dengan benar dan baik.

Tabel 3. Distribusi subjek penelitian berdasarkan cara menyikat gigi yang benar dan baik

\begin{tabular}{ccc}
\hline $\begin{array}{c}\text { Cara menyikat gigi yang } \\
\text { benar dan baik }\end{array}$ & $\mathrm{n}$ & $\%$ \\
\hline Ya & 45 & 100 \\
Tidak & 0 & 0 \\
Total & 45 & 100 \\
\hline
\end{tabular}

Pada Tabel 4 berdasarkan metode menyikat gigi dari 45 subjek penelitian, terdapat 33 siswa $(73,3 \%)$ yang menyikat gigi dengan cara kombinasi (gerakan memutar, maju-mundur dan atas-bawah), 8 siswa $(17,8 \%)$ yang menyikat gigi dengan cara horizontal (gerakan maju-mundur), dan 4 siswa (8,9\%) yang menyikat gigi dengan cara vertical (gerakan atas-bawah).

Tabel 4. Distribusi subjek penelitian berdasarkan metode menyikat gigi

\begin{tabular}{ccc}
\hline Metode menyikat gigi & $\mathrm{N}$ & $\%$ \\
\hline Kombinasi & 33 & 73,3 \\
Horizontal & 8 & 17,8 \\
Vertikal & 4 & 8,9 \\
Total & 45 & 100 \\
\hline
\end{tabular}

Pada Tabel 5 berdasarkan menyikat gigi malam hari sebelum tidur dapat dilihat bahwa semua siswa (100\%) menyikat gigi malam hari sebelum tidur.

Tabel 5. Distribusi subjek penelitian berdasarkan menyikat gigi malam hari sebelum tidur

\begin{tabular}{ccc}
\hline $\begin{array}{c}\text { Menyikat gigi malam } \\
\text { hari sebelum tidur }\end{array}$ & $\mathrm{n}$ & $\%$ \\
\hline Ya & 45 & 100 \\
Tidak & 0 & 0 \\
\hline Total & 45 & 100 \\
\hline
\end{tabular}

\section{Hasil Penelitian Status Gingiva}

Tabel 6 menunjukkan dari 45 subjek penelitian, terdapat 4 siswa $(8,9 \%)$ yang memiliki status gingiva dengan kriteria normal, 25 siswa $(55,6 \%)$ dengan kriteria inflamasi ringan, dan 16 siswa $(35,5 \%)$ dengan kriteria inflamasi sedang. Tidak terdapat siswa $(0 \%)$ yang memiliki status gingiva dengan kriteria inflamasi berat.

Tabel 6. Distribusi status gingival berdasarkan pengukuran dengan menggunakan GI

\begin{tabular}{ccc}
\hline Status gingiva & $\mathrm{n}$ & $\%$ \\
\hline Normal & 4 & 8,9 \\
Inflamasi ringan & 25 & 55,6 \\
Inflamasi sedang & 16 & 35,5 \\
Inflamasi berat & 0 & 0 \\
Total & 45 & 100 \\
\hline
\end{tabular}

Tabel 7 memperlihatkan status gingiva berdasarkan menyikat gigi malam hari sebelum tidur. Dari 45 subjek penelitian, terdapat sejumlah 4 siswa (8,9\%) yang memiliki status gingiva dengan kriteria normal yang menyikat gigi malam hari sebelum tidur; 25 siswa (55,6\%) yang memiliki status gingiva dengan kriteria inflamasi ringan yang menyikat gigi malam hari sebelum tidur; dan 16 siswa (35,5\%) yang memiliki status gingiva dengan kriteria inflamasi sedang yang menyikat gigi malam hari sebelum tidur. Status gingiva dengan kriteria inflamasi berat tidak ditemukan pada siswa-siswi pada penelitian ini.

\section{BAHASAN}

Berdasarkan umur responden sebagian besar siswa termasuk pada kategori umur 10 tahun yang berjumlah 12 siswa $(26,7 \%)$, umur 11 tahun sebanyak 18 siswa (40\%) dan umur 12 tahun sebanyak 15 siswa (33,3\%).

Menyikat gigi merupakan salah satu kegiatan pembersihan rongga mulut yang paling sederhana dan efektif. Kegiatan ini antara lain bertujuan membersihkan permukaan gigi dari plak yang menempel. Efektifitas dari penyikatan gigi ditentukan oleh keterampilan menyikat gigi yang meliputi faktor metode, durasi dan frekuensi menyikat gigi. 
Maruanaya, Mariati, Pangemanan: Gambaran status gingiva menurut kebiasaan ...

Tabel 7. Distribusi status gingiva berdasarkan menyikat gigi malam hari sebelum tidur

\begin{tabular}{|c|c|c|c|c|c|c|c|c|c|c|}
\hline \multirow{3}{*}{$\begin{array}{l}\text { Menyikat gigi } \\
\text { malam sebelum } \\
\text { tidur }\end{array}$} & \multicolumn{8}{|c|}{ Status gingiva } & & \\
\hline & \multicolumn{2}{|c|}{$\begin{array}{c}\text { Gingiva } \\
\text { normal }\end{array}$} & \multicolumn{2}{|c|}{$\begin{array}{l}\text { Inflamasi } \\
\text { ringan }\end{array}$} & \multicolumn{2}{|c|}{$\begin{array}{l}\text { Inflamasi } \\
\text { sedang }\end{array}$} & \multicolumn{2}{|c|}{$\begin{array}{c}\text { Inflamasi } \\
\text { berat }\end{array}$} & \multicolumn{2}{|c|}{ Total } \\
\hline & $\mathrm{n}$ & $\%$ & $\mathrm{n}$ & $\%$ & $\mathrm{n}$ & $\%$ & $\mathrm{n}$ & $\%$ & $\mathrm{n}$ & $\%$ \\
\hline Ya & 4 & 8,9 & 25 & 55,6 & 16 & 35,5 & 0 & 0 & 45 & 100 \\
\hline Tidak & 0 & 0 & 0 & 0 & 0 & 0 & 0 & 0 & 0 & 0 \\
\hline Total & 4 & 8,9 & 25 & 55,6 & 16 & 35,5 & 0 & 0 & 45 & 100 \\
\hline
\end{tabular}

Berdasarkan hasil penelitian, semua subjek (100\%) tahu tentang tujuan menjaga kesehatan gigi dan mulut yaitu dengan cara menyikat gigi dan juga tahu cara menyikat gigi yang benar dan baik.

Selain tujuan dan cara menyikat gigi, hal penting lainnya yang harus diperhatikan ialah metode menyikat gigi. Hasil penelitian menunjukkan sebagian besar responden $(73,3 \%)$ menyikat gigi dengan menggunakan metode kombinasi. Metode kombinasi merupakan metode gabungan antara beberapa gerakan dalam menyikat gigi, antara lain serakan memutar (metode Rolling Stroker), gerakan maju-mundur (metode Bass) dan gerakan atas-bawah (metode Charter). Secara umum juga para ahli menyimpulkan bahwa cara menyikat gigi yang paling efektif ialah dengan mengombinasikan metode-metode yang ada. $^{6}$

Selain metode menyikat gigi, hal penting lainnya yang harus diperhatikan ialah durasi menyikat gigi. Durasi menyikat gigi sekurang-kurangnya 2 menit sudah mencukup seluruh permukaan gigi. ${ }^{7}$ Data penelitian menunjukkan sebanyak 48,9\% siswa-siswi menyikat gigi kurang dari 2 menit. Hal ini menggambarkan bahwa durasinya sudah baik karena jika menyikat gigi lebih dari 2 menit akan mengakibatkan gigi abrasi dan rasa ngilu pada gigi. ${ }^{8}$

Efektifitas menyikat gigi selain ditentukan oleh faktor di atas, juga ditentukan oleh frekuensi menyikat gigi. Hasil penelitian menunjukkan sebagian besar responden $(75,6 \%)$ anak menyikat gigi 2 kali sehari, dimana semua subjek telah melakukan dengan benar, yakni menyikat gigi pada waktu pagi setelah sarapan dan malam sebelum tidur. Menurut Claessen et al. waktu menyikat yang tepat untuk menyikat gigi adalah setelah sarapan pagi dan sebelum tidur malam. ${ }^{7}$

Berdasarkan hasil pemeriksaan status gingiva yang diukur dengan menggunakan Gingiva Index paling banyak ditemukan status gingiva dengan kategori inflamasi ringan (55,6\%). Berdasarkan wawancara dan pemeriksaan yang dilakukan, siswasiswi di Sekolah Dasar Negeri 70 Manado sudah memahami mengenai menyikat gigi yang baik dan benar. Hasil ini serupa dengan penelitian yang dilakukan Ahmad di Sekolah Dasar 060884 Kecamatan Medan Baru yang menunjukkan status kebersihan mulut dengan kategori ringan 14,9\% dan dengan kategori buruk 49\%. ${ }^{9}$

Distribusi status gingiva berdasarkan menyikat gigi malam hari sebelum tidur di Sekolah Dasar Negeri 70 Manado menunjukkan 25 siswa-siswi (55,5\%) yang memiliki status gingiva dengan kriteria inflamasi ringan yang menyikat gigi malam hari sebelum tidur. Penyebab inflamasi ringan pada status gingiva berdasarkan menyikat gigi malam hari sebelum tidur yaitu menyikat gigi terlalu lama atau lebih dari 2 menit, tekanan pada saat menyikat gigi terlalu keras, bulu sikat gigi yang digunakan terlalu keras (tidak memakai sikat gigi anak).

Distribusi status gingiva berdasarkan frekuensi menyikat gigi pada siswa-siswi di Sekolah Dasar Negeri 70 Manado menunjukkan sejumlah 25 siswa-siswi (55,5\%) yang memiliki status gingiva dengan kriteria inflamasi ringan yang 
menyikat gigi 2 kali sehari sejumlah 20 siswa-siswi (44,4\%). Hal ini menunjukkan bahwa siswa yang melakukan penyikatan gigi 2 kali sehari memiliki status gingiva yang lebih baik dibandingkan dengan siswa-siswi yang melakukan penyikatan gigi lebih dari 2 kali sehari. Hasil SKRT tahun 2000 menunjukkan bahwa pada anak-anak usia sekolah dasar terdapat 23,4\% anak yang tidak menyikat giginya, $5,6 \%$ anak yang menyikat giginya pada waktu yang tepat. Hal tersebut disebabkan kurangnya pengetahuan anak-anak Sekolah Dasar mengenai waktu yang tepat untuk menyikat gigi. ${ }^{10}$

Distribusi status gingiva berdasarkan durasi menyikat gigi pada siswa-siswi di Sekolah Dasar Negeri 70 Manado menunjukkan 24 siswa-siswi (53,3\%) yang memiliki status gingiva dengan kriteria inflamasi ringan yang menyikat gigi kurang dari 2 menit sejumlah 11 siswa-siswi (24,4\%). Data tersebut menunjukkan bahwa waktu siswa-siswi menyikat gigi yaitu kurang dari 2 menit. Hal ini menggambarkan bahwa durasinya sudah baik karena jika menyikat gigi lebih dari 2 menit akan mengakibatkan gigi abrasi dan rasa ngilu pada gigi. ${ }^{8}$

Distribusi status gingiva berdasarkan metode menyikat gigi pada siswa-siswi di Sekolah Dasar Negeri 70 Manado menunjukkan bahwa dari sejumlah 24 siswa-siswi $(53,3 \%)$ yang memiliki status gingiva dengan kriteria inflamasi ringan, 20 siswa-siswi $(44,4 \%)$ diantaranya menyikat gigi dengan cara kombinasi. Data tersebut menunjukkan bahwa siswa-siswi paling banyak menggunakan metode kombinasi. Hal yang sama dikemukakan oleh Ganta yang meneliti siswa-siswi di Sekolah Dasar Katolik 05 Theodorus Moors di Manado pada tahun 2012, dimana sebanyak 41,4\% siswa-siswi menyikat gigi menggunakan metode kombinasi. ${ }^{11}$

\section{SIMPULAN}

Berdasarkan penelitian yang dilakukan pada siswa-siswi Sekolah Dasar Negeri 70 Manado usia 10 - 12 tahun dengan jumlah 45 siswa, disimpulkan bahwa berdasarkan pengukuran indeks gingiva menunjukkan bahwa sebagian besar siswa memiliki status gingiva dengan kriteria inflamasi ringan. Status gingiva berdasarkan menyikat gigi sebelum tidur malam hari menunjukkan bahwa sebagian besar siswa menyikat gigi sebelum tidur malam hari.

\section{SARAN}

1. Bagi masyarakat khususnya para orang tua sebaiknya lebih memperhatikan kebersihan mulut anaknya dengan memberikan pendidikan tentang kesehatan gigi dan mulut yaitu mengajari anak menyikat gigi yang benar terutama menyikat gigi malam hari sebelum tidur dan meluangkan waktu memeriksa gigi anak serta memperkenalkan dokter gigi sejak dini.

2. Bagi pemerintah dalam hal ini Dinas Kesehatan Kota Manado dan jajaran dibawahnya dalam pembenahan program yang telah ada dalam rangka meningkatkan status kesehatan masyarakat terlebih khusus status kesehatan gigi masyarakat kota Manado.

3. Perlu adanya tindaklanjut dari pihak sekolah bekerjasama dengan pihak puskesmas untuk menjalankan program UKGS (Usaha Kesehatan Gigi dan Mulut Sekolah) guna mendidik, membentuk serta meningkatkan perilaku kesehatan gigi dan mulut anak yang baik.

4. Perlu dilakukan penelitian lebih lanjut dan meluas mengenai kesehatan gigi dan mulut pada anak-anak usia sekolah dasar.

\section{DAFTAR PUSTAKA}

1. Lindhe J, Lang NP, Karring T, editors. Clinical periodontology and implant Dentistry (5th ed.). New York: Blackwell Munksgaard, 2008; p. 13396.

2. Newman MG, Takei HH, Kolkkevold PR, Carranza FA, editors. Carranza's Clinical periodontology (10th ed.). Philadelphia: Saunders Company, 2006; p. 728-45.

3. Hadnyanawati H. Hubungan kebersihan gigi dan mulut dengan gingivitis pada 
siswa sekolah dasar kelas $\mathrm{V}$ di kabupaten Jember. Jurnal Kedokteran Gigi Universitas Indonesia. 2002:9(2): 10-12.

4. Darwita RR, Rahardjo A, Amalia R. Penerimaan guru SDN 03 Senen terhadap program sikat gigi bersama di dalam kelas pada murid kelas 1 dan 2 . Cakradonya Dent J. 2010;2(2):159-250.

5. Laporan Riset Kesehatan Dasar Nasional 2013. Jakarta: Badan penlitian dan pengembangan kesehatan kementrian kesehatan RI [serial online]. 2013 [Cited 2014 Feb];111,116-17. Available from: www.litbang.depkes.go.id.

6. Sing. Preventing dental caries in children at hign caries risk. A national clinical guideline [serial online] 2000 [cited 2012 Mar 12]; (47):8. Available from: URL: http:www.sign.ac.uk/pdf/sign47.pdf.

7. Anitasari S, Rahayu E. Hubungan frekuensi menyikat gigi dengan tingkat kebersihan gigi dan mulut siswa sekolah dasar negeri di Kecamatan
Palaran Kotamadya Samarinda Provinsi Kalimantan Timur. Maj Ked Gigi. 2005:38(2);88-90.

8. Ramsay DS. Patient compliance with oral hygiene regimens: A behavioural selfregulation analysis with implications for technology. International Dental Journal. 2000:312-23.

9. Prevention Indonesia. 10 Cara menggosok gigi dengan baik. [serial online] 2009 [cited 2012 April 20]. Available from: URL:

http://www.tabloidnova.com/Nova/Tips /10-Cara-Menggosok-Gigi-Yang-Baik

10. McDonald RE, Avery DR, Dean JA. Dentistry for the child and adolescent (8th ed.). Indiana: Mosby, 2004.

11. Ganta HY. Gambaran status gingiva berdasarkan pola penyikatan gigi pada anak usia 8-12 tahun di SD Katolik 05 Theodorus Moors Kecamatan Tuminting Kota Manado. Available from. http://ejournal.unsrat.ac.id/index.php/eg igi/article/view/3145. 